\title{
Results of Tritium Tracking and Groundwater Monitoring at the Hanford Site 200 Area State- Approved Land Disposal Site-Fiscal Year 2000
}

D. B. Barnett

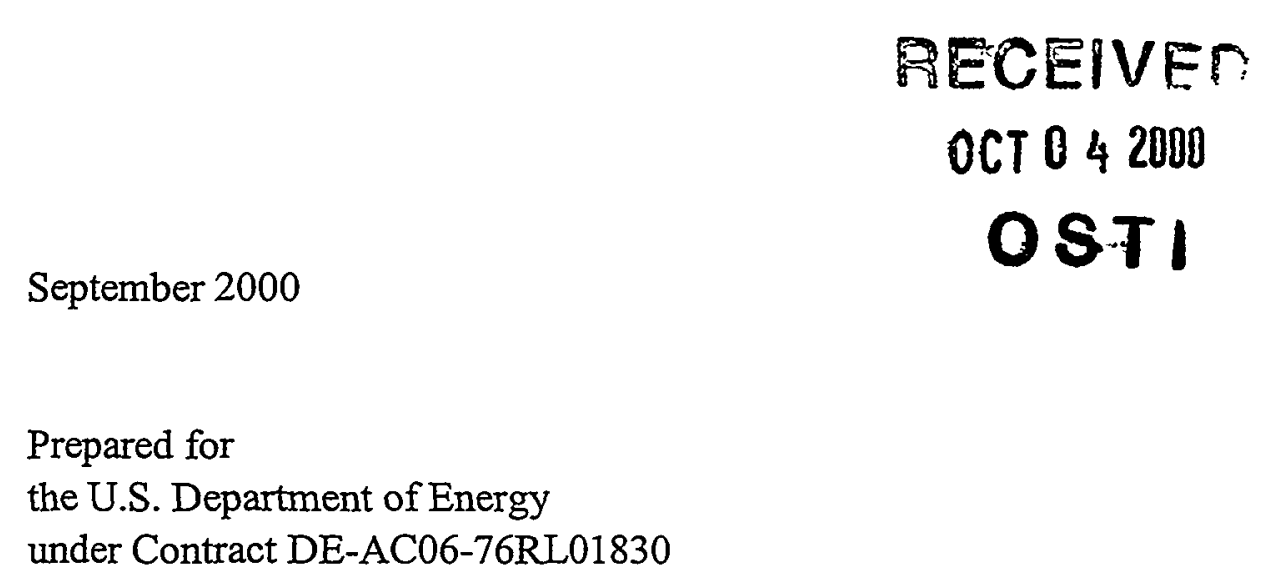

Pacific Northwest National Laboratory Richland, Washington 99352 


\section{DISCLAIMER}

This report was prepared as an account of work sponsored by an agency of the United States Government. Neither the United States Government nor any agency thereof, nor any of their employees, make any warranty, express or implied, or assumes any legal liability or responsibility for the accuracy, completeness, or usefulness of any information, apparatus, product, or process disclosed, or represents that its use would not infringe privately owned rights. Reference herein to any specific commercial product, process, or service by trade name, trademark, manufacturer, or otherwise does not necessarily constitute or imply its endorsement, recommendation, or favoring by the United States Government or any agency thereof. The views and opinions of authors expressed herein do not necessarily state or reflect those of the United States Government or any agency thereof. 


\section{DISCLAIMER}

Portions of this document may be illegible in electronic image products. Images are produced from the best available original document. 


\section{Summary}

The Hanford Site 200 Area Effluent Treatment Facility (ETF) processes contaminated liquids derived from Hanford Site facilities. The clean water generated by these processes is occasionally enriched in tritium, and is discharged to the 200 Area State Approved Land Disposal Site (SALDS). Groundwater monitoring for tritium and other constituents is required by the state-issued permit at 22 wells surrounding the facility.

Water level measurements in nearby wells indicate that a small hydraulic mound exists around the SALDS facility as a result of discharges. This feature is directing groundwater flow radially outward a short distance before the regional northeasterly flow predominates. Evaluation of this condition indicates that the network is currently adequate for tracking potential effects of the SALDS on the groundwater.

During FY 2000, average tritium activities in most wells declined from average activities in 1999. The exceptions are deep well $699-48-77 \mathrm{C}$, where tritium results reached a maximum value of $710,000 \mathrm{pCi} / \mathrm{L}$ as a result of the delayed penetration of effluent deeper into the aquifer, and in well 299-W7-3, along the northern boundary of the 200 West Area, which has apparently been affected for the first time by the SALDS tritium plume, with a tritium activity of $1,400 \mathrm{pCi} / \mathrm{L}$ measured in August 2000. Of the 12 constituents with permit enforcement limits, which are monitored in SALDS proximal wells, all were within groundwater limitations during FY 2000.

The arrival of tritium at well 299-W7-3 demonstrates excellent agreement with the current numerical groundwater model, by virtue of both arrival time and predicted tritium concentration.

Analyses for conductivity, total dissolved solids, sulfate, chloride, sulfate, dissolved calcium, and dissolved sodium indicate that well 699-48-77A and, to a lesser extent, well 699-48-77D show the effects of dilute effluent entering groundwater, resulting in a depression of concentrations of these constituents below natural background levels.

Recommendations for future monitoring include temporarily increasing the frequency of tritium sampling at wells 299-W7-3, 299-W7-5, 299-W7-6, and 299-W7-7 to quarterly. This measure will assist in a more accurate determination of the southern bounds of the SALDS-generated tritium plume, provide estimates of travel time for model comparisons, and help preserve the distinction between this plume and the older 200 West tritium plume further east. Because of the accurate numerical model predictions thus far, reapplication of the model will occur only after a recognizable departure from model predictions is observed through the increased frequency in well monitoring. 



\section{Acknowledgments}

The author extends his appreciation to reviewers M. J. Hartman (PNNL) and P. M. Olson (Fluor Hanford, Inc.) and to K. R. Neiderhiser and L. M. Andor (PNNL) for arrangement and processing of the document. Thanks are also extended to C. A. Newbill and J. T. Rieger (PNNL), and Dennis Brunson (Lockheed Martin Services) for graphics support. 



\section{Contents}

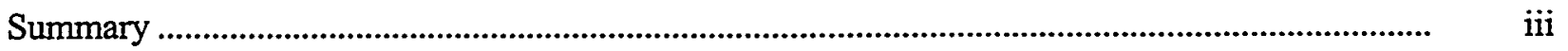

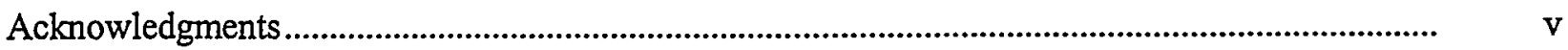

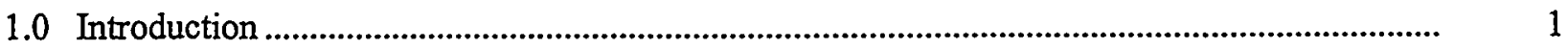

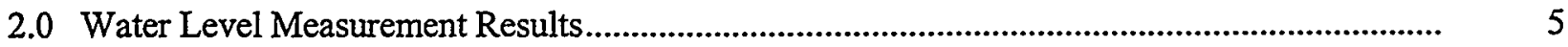

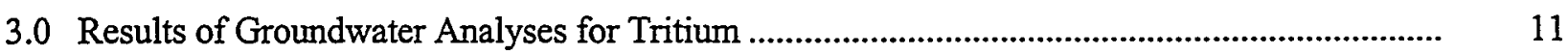

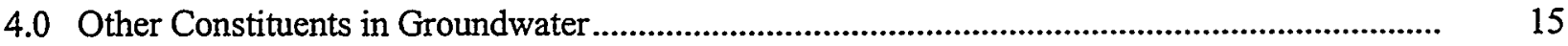

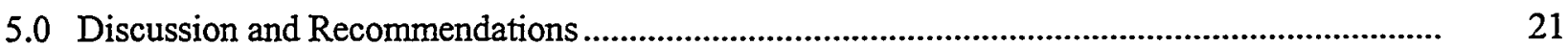

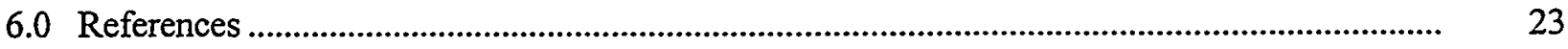

Appendix A - SALDS Tritium Results in Groundwater for FY 2000........................................ A.1

vii 


\section{Figures}

1 Location of the State-Approved Land Disposal Site and Related Infrastructure ...................... 2

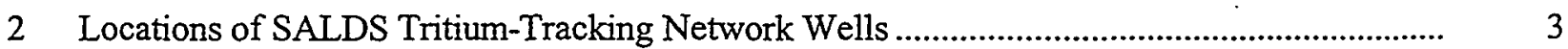

3 Hydrographs of Tritium Tracking Wells North, Northwest, and East of the SALDS, Compared with Well 699-48-77A, and SALDS Proximal Wells

4 Hydrographs of Tritium Tracking Wells Southwest and South of the SALDS, Compared with Well 699-48-77A

5 Hydrographs of Tritium Tracking Wells Southeast of SALDS Compared with Well 699-48-77A, and Deep/Shallow Companion Wells.

6 Water Table Map and Interpreted Groundwater Flow Directions in the SALDS Area for March 2000

7 Maximum Tritium Activities in Groundwater for the SALDS Tritium-Tracking Network for FY 2000, Indicating Change from FY 1999

8 Tritium Activity Trends in SALDS Proximal Wells Through August 2000

9 Tritium Activity Trends in Wells Southeast of the SALDS, Showing Remnant Effects of the Tritium Plume from the 200 West Area, and Recent Changes in Trends for Wells 299-W7-3 and 299-W7-7.

10 Trend Plots for Conductivity and Total Dissolved Solids in SALDS Proximal Wells and Well 299-W8-1

11 Trend Plots for Chloride and sulfate in SALDS Proximal Wells and Well 299-W8-1

12 Trend Plots for Dissolved Calcium and Dissolved Sodium for SALDS Proximal Wells and Well 299-W8-1

\section{Table}

1 Maximum Concentrations of Constituents with Permit Enforcement Limits in Groundwater and Corresponding Sample Month, SALDS, FY 2000 


\subsection{Introduction}

Treated water from the $200^{\circ}$ Area Effluent Treatment Facility (ETF) is discharged to a disposal site as allowed by State Waste Discharge Permit ST-4500 (ST-4500). The permit allows disposal of tritium to the disposal site, which is named the State-Approved Land Disposal Site (SALDS), and is located immediately north of the 200 West Area of the Hanford Site (Figure 1). In accordance with ST-4500, the groundwater in the vicinity of the SAIDS is routinely sampled and water levels in wells are measured. The results of the groundwater sampling and analysis are reported in quarterly discharge monitoring reports. In 1997, the USDOE also recommended the issuance of an annual summary report of groundwater monitoring results and evaluation, with updates to the groundwater monitoring plan, as appropriate. This report summarizes the results of groundwater analyses and information for the SALDS during FY 2000.

In August 2000, a renewal of ST-4500 was approved for the ETF and SALDS for years 2000-2005. The new ST-4500 effected a few changes in groundwater monitoring at the SALDS; most notably, the elimination of a formerly-upgradient well for determination of background groundwater quality. This well, 299-W8-1, has not been hydraulically upgradient of the SALDS since shortly after the beginning of SALDS operation, and thus does not represent groundwater upstream of the facility. The list of constituents and the enforcement limits ("groundwater limitations") for these remain virtually the same in the new version of ST -4500 , except that ammonia was removed from the list. The history of the facility, with respect to groundwater monitoring, and the new groundwater monitoring plan dictated by ST -4500 , are described by Barnett (2000).

Both the old and new versions of ST -4500 contain provisions for update of a numerical groundwater model at least once during a permit cycle ( 5 years) to predict tritium movement and distribution in the aquifer resulting from SALDS discharges. The new version of ST-4500 also requires that the model be reapplied "within 6 months of detection of the tritium plume in a new monitoring well." This provision indicates that the numerical model will be reapplied when the tritium plume associated with the SALDS is positively identified in a location not predicted by the current model run or at a concentration greater than that predicted.

Wells in the groundwater monitoring network (Figure 2) are sampled quarterly to annually for constituents regulated by the State Waste Discharge Permit. Wells $699-48-77 \mathrm{~A}, 699-48-77 \mathrm{C}$, and 699-48-77D are part of the proximal monitoring network designed to detect near-term effects on groundwater of the SALDS operation. These three wells are sampled quarterly for tritium and a list of constituents governed by ST -4500 . An additional 19 wells are sampled semiannually to annually for tritium only. Wells 299-W7-3, 299-W7-5, 299-7-6, 299-W7-7, 299-7-11, and 699-51-75 are sampled semiannually; the remaining 14 wells are sampled annually. Well 699-51-75P, a deep companion to well 699-51-75, was added to the network during FY 2000 to detect tritium deeper within the aquifer. Well 299-W8-1, the former upgradient well, was recently rescheduled to be sampled for tritium only on an annual basis. 


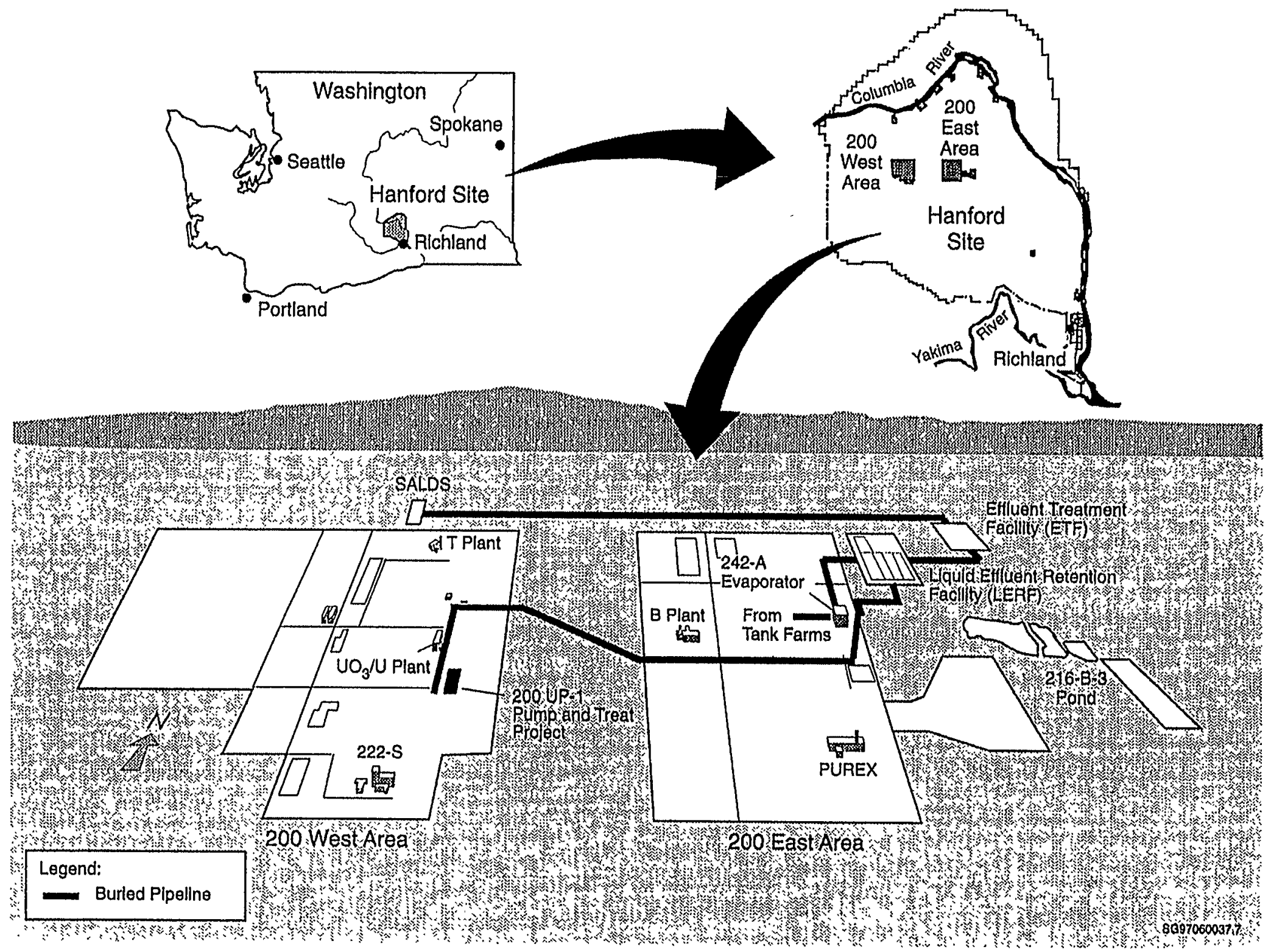

Figure 1. Location of the State-Approved Land Disposal Site and Related Infrastructure 


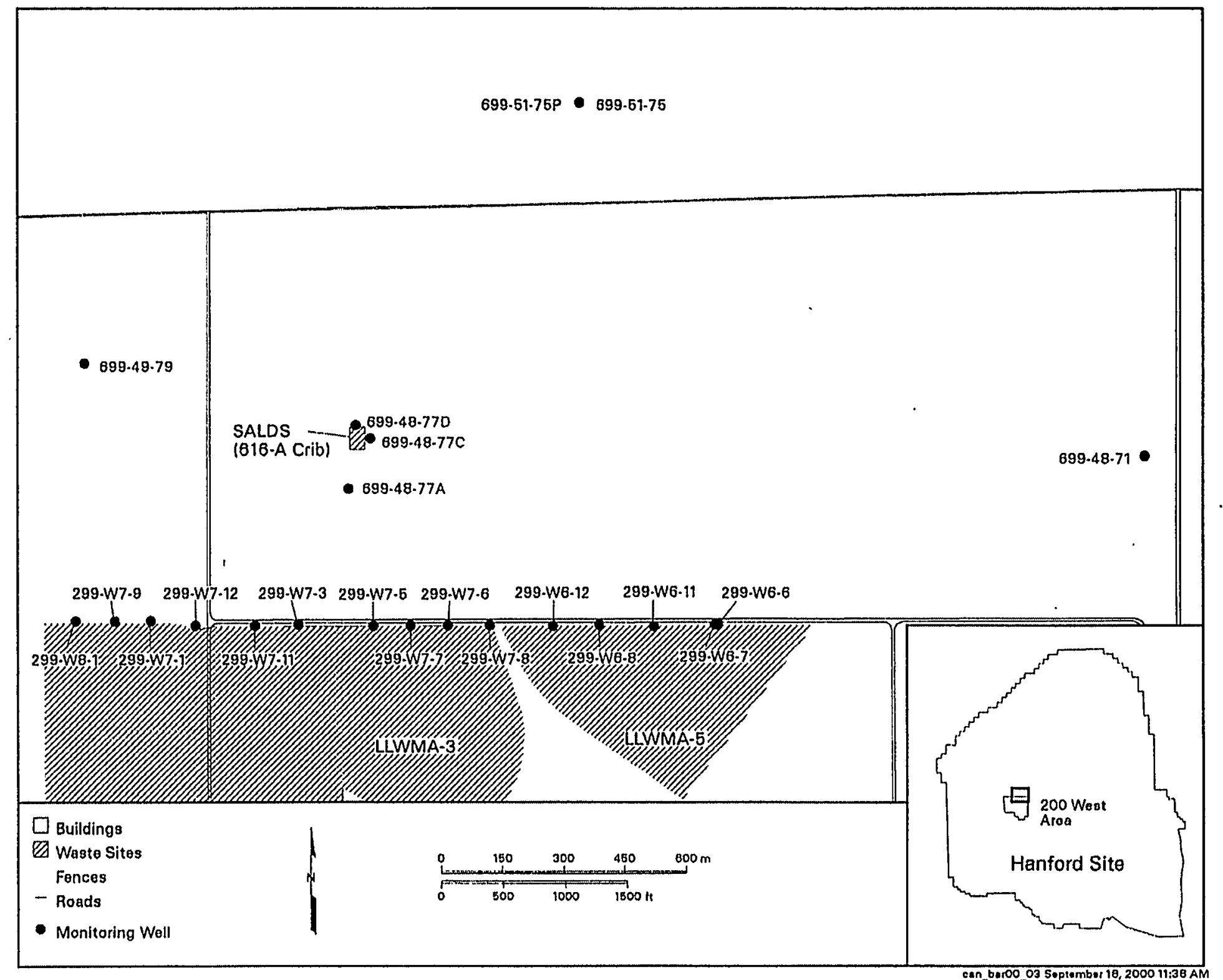

Figure 2. Locations of SALDS Tritium-Tracking Network Wells 


\subsection{Water Level Meásurement Results}

Water levels are measured in wells prior to each sampling event. Additionally, water levels have been measured monthly, since January 1997 in the proximal SALDS facility wells (699-48-77A, 699-48-77C, and 699-48-77D) and former upgradient well 299-W8-1. Hydrographs for these wells (through August 2000) and the remaining wells in the tritium-tracking network, grouped by relative position to the SALDS, are shown in Figures 3 through 5.

Hydraulic head in well 699-48-77A has consistently surpassed the head in "upgradient" well 299-W8-1 and most other wells in the tritium-tracking network since late 1997 (Figures 3-5). This is a result of the continuing general decline in water levels in the 200 West Area combined with the increased head near the SALDS, resulting from SALDS operation. This condition will become more pronounced as the water table continues to decline in the vicinity of 200 West Area.

Hydrographs of deep and shallow tritium-tracking network wells, 299-W6-6 and 299-W6-7 respectively, indicate that almost no vertical gradient exists in this portion of the aquifer away from the SALDS vicinity (Figure 5). This condition explains the lack of tritium from the 200 West Area plume in the deep well, while the shallow well shows high levels of tritium. During operational discharges in the 200 West Area, tritium was apparently not forced down to lower portions of the aquifer in this region. Near the SALDS, a consistently downward potential exists in the aquifer, as indicated by the head differences between the shallow proximal wells $699-48-77 \mathrm{~A}, 699-43-77 \mathrm{D}$, and deeper proximal well $699-48-77 \mathrm{C}$ (Figure 3).

An interpretation of the water table in the vicinity of the SALDS for March 2000 is shown in Figure 6. The groundwater mound associated with SAIDS operation is evident near the facility. The center of the mound is not necessarily located at well 699-48-77A; its shown location is partially an artifact of well coverage at the SALDS and is an approximate location, with the actual center probably located somewhere between well 699-48-77A and the facility. Arrows denoting the interpreted flow paths (or the potential for flow) of groundwater in the vicinity of the SALDS indicate that effluent from the SALDS could eventually affect wells to the south of the facility. Exactly how far south the effluent from SALDS could actually flow before turning east is not known. However, recent (late August 2000) analyses for tritium in well 299-W7-3 indicate an increase in activity, and may provide a basis for calculating flow rates at a distance from the SALDS (see discussion in Section 5.0). Importantly, downgradient well 699-51-75 is apparently in an optimum location for the interception and efficient tracking of tritium in a regionally-downgradient direction from the SALDS. 

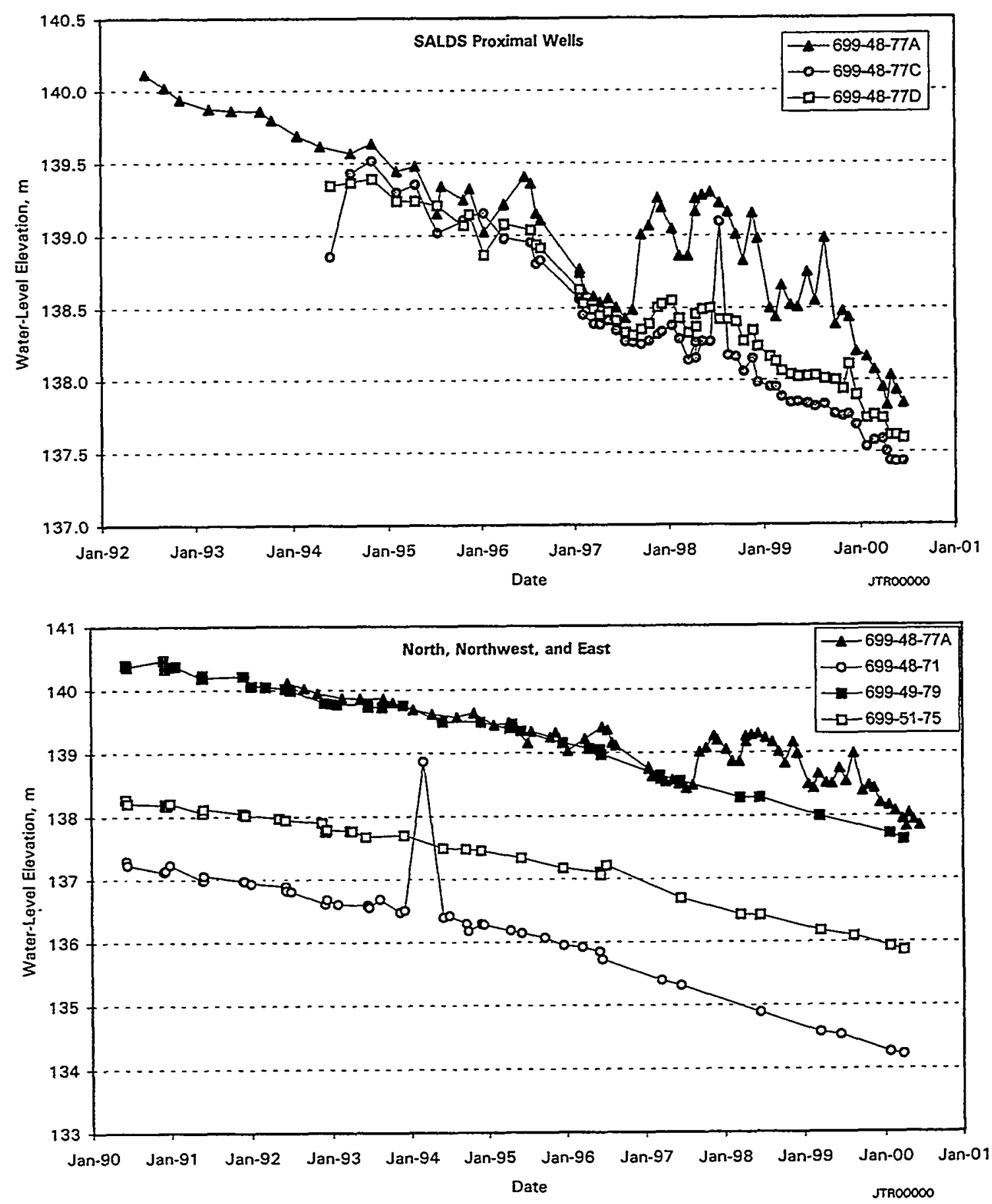

Figure 3. Hydrographs of Tritium Tracking Wells North, Northwest, and East of the SALDS, Compared with Well 699-48-77A (top), and SALDS Proximal Wells (bottom). Well 699-48-77C is completed (screen) 20 m deeper within the aquifer than the other two proximal wells. 


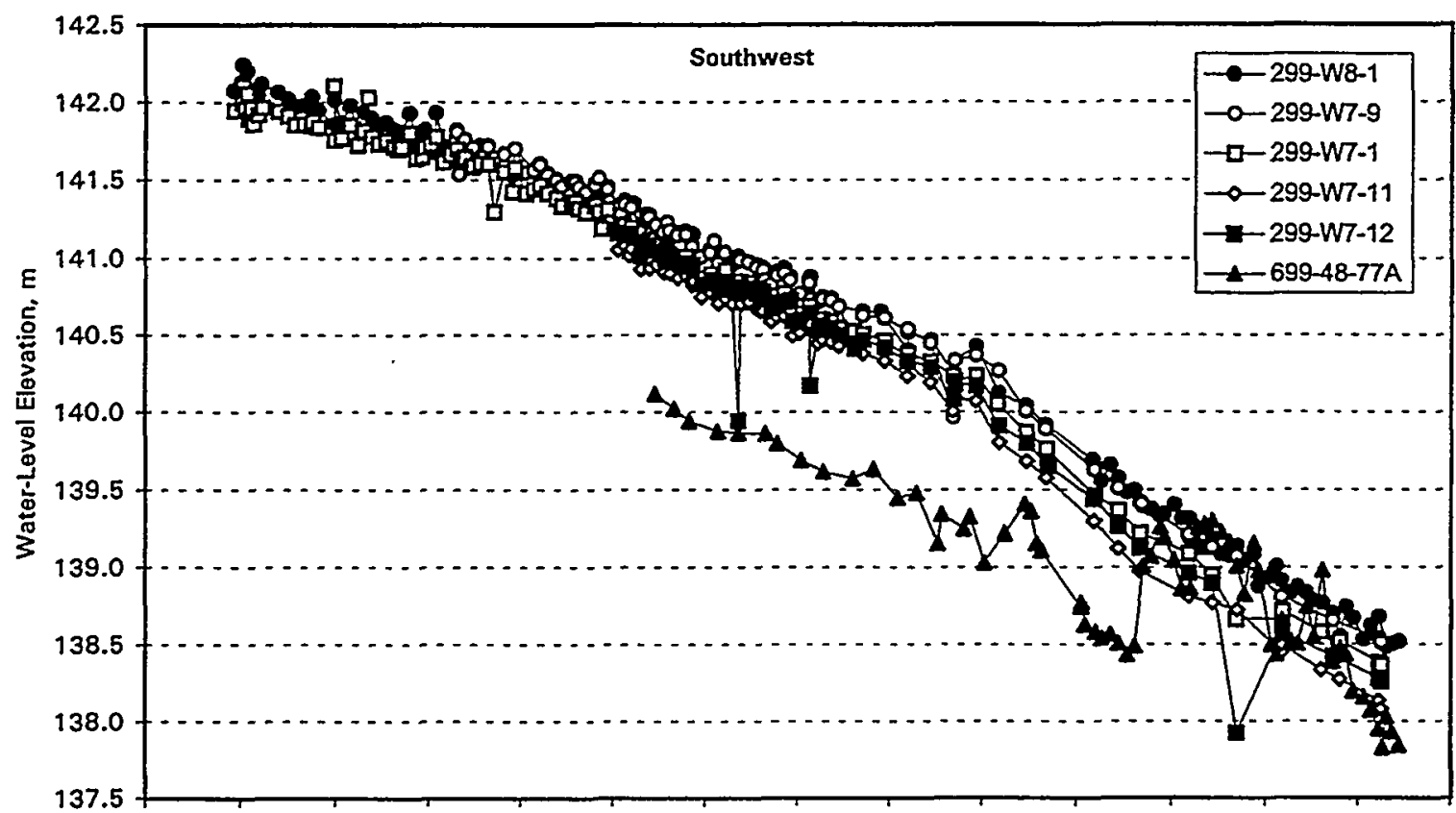

Jan-87 Jan-88 Jan-89 Jan-90 Jan-91 Jan-92 Jan-93 Jan-94 Jan-95 Jan-96 Jan-97 Jan-98 Jan-99 Jan-00 Jan-01

Date

JrR00000

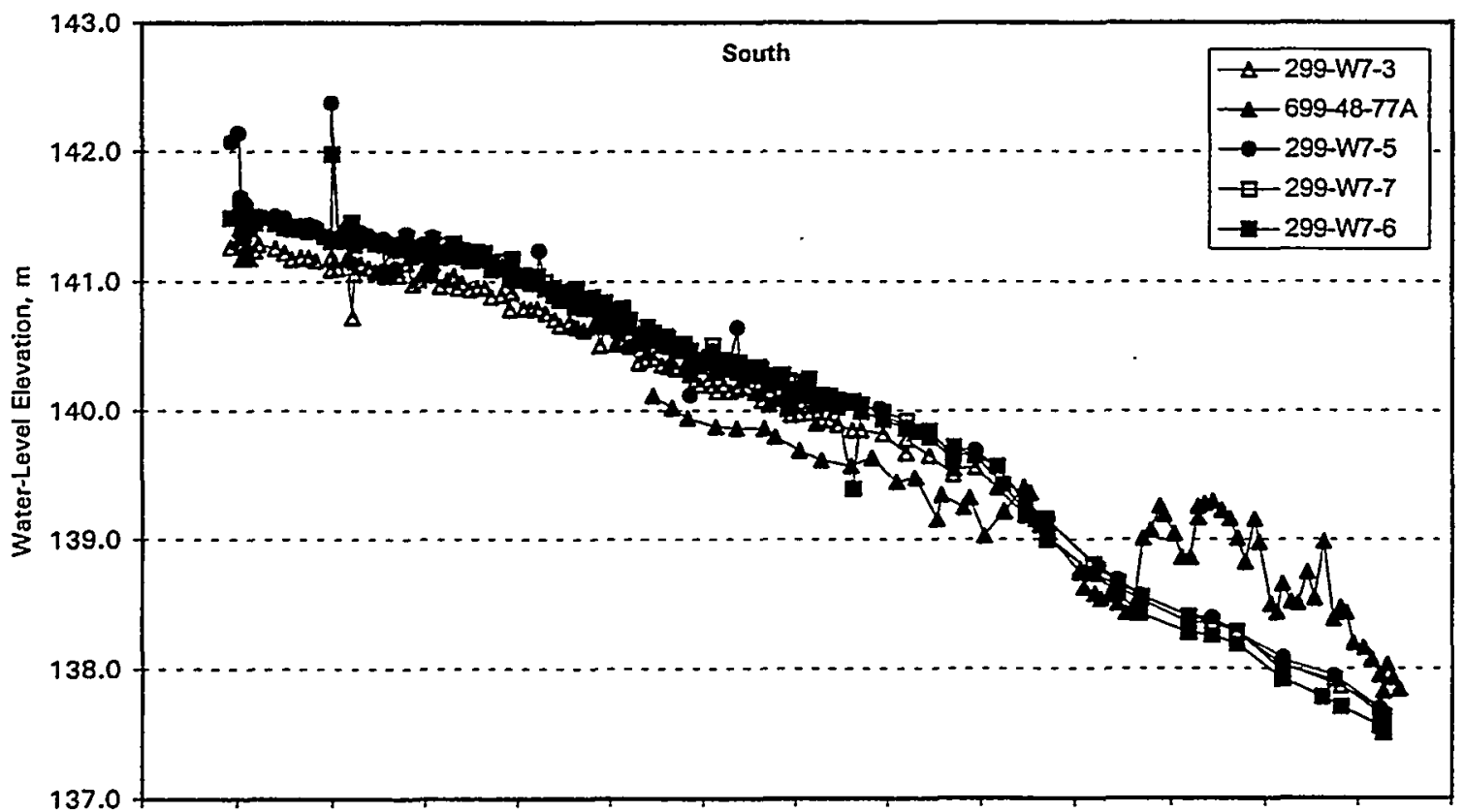

Jan-87 Jan-88 Jan-89 Jan-90 Jan-91 Jan-92 Jan-93 Jan-94 Jan-95 Jan-96 Jan-97 Jan-98 Jan-99 Jan-00 Jan-01

Date

JTR00000

Figure 4. Hydrographs of Tritium Tracking Wells Southwest (top) and South (bottom) of the SALDS, Compared with Well 699-48-77A 

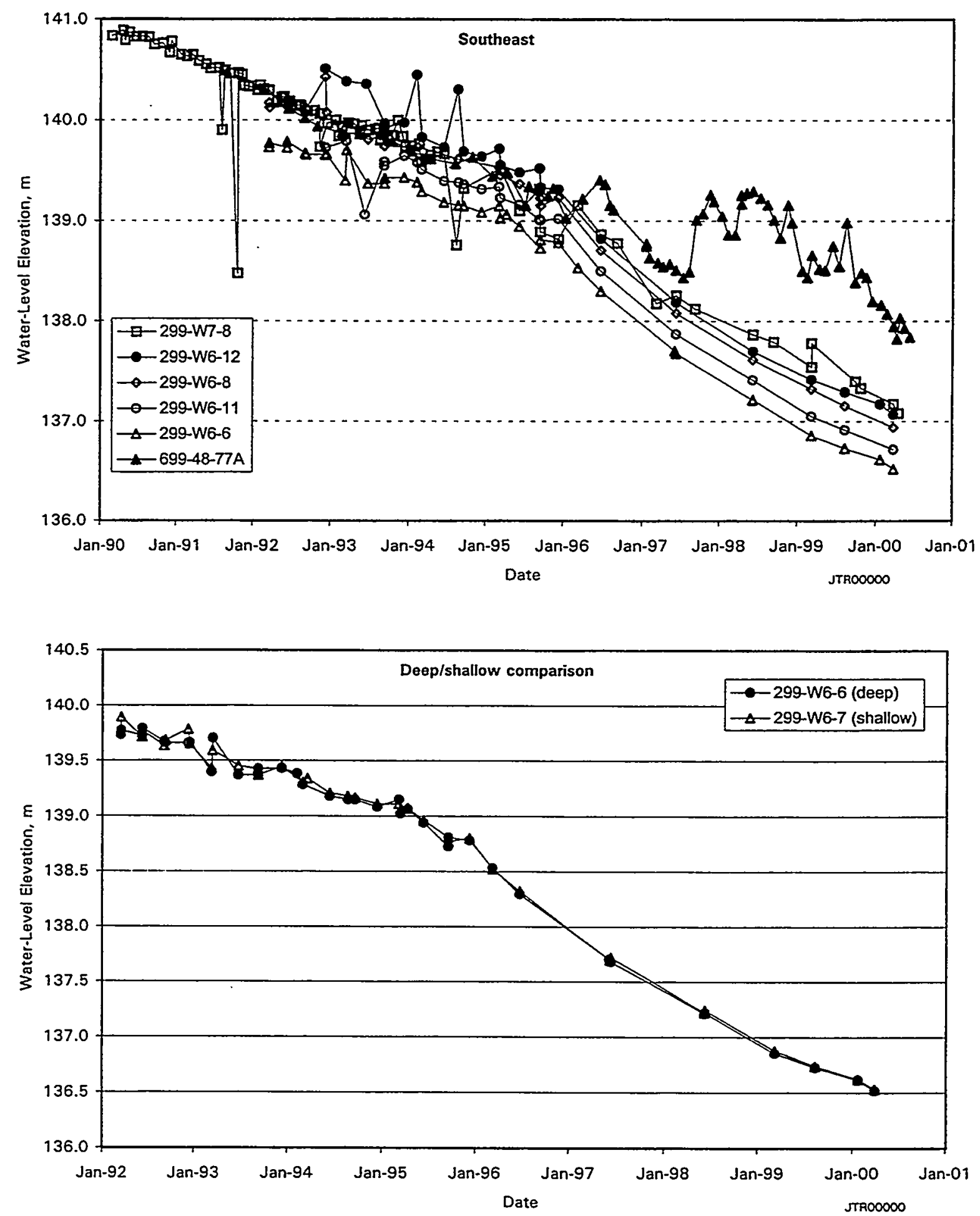

Figure 5. Hydrographs of Tritium Tracking Wells Southeast of SALDS Compared with Well 699-48-77A (top), and Deep/Shallow Companion Wells (bottom) 


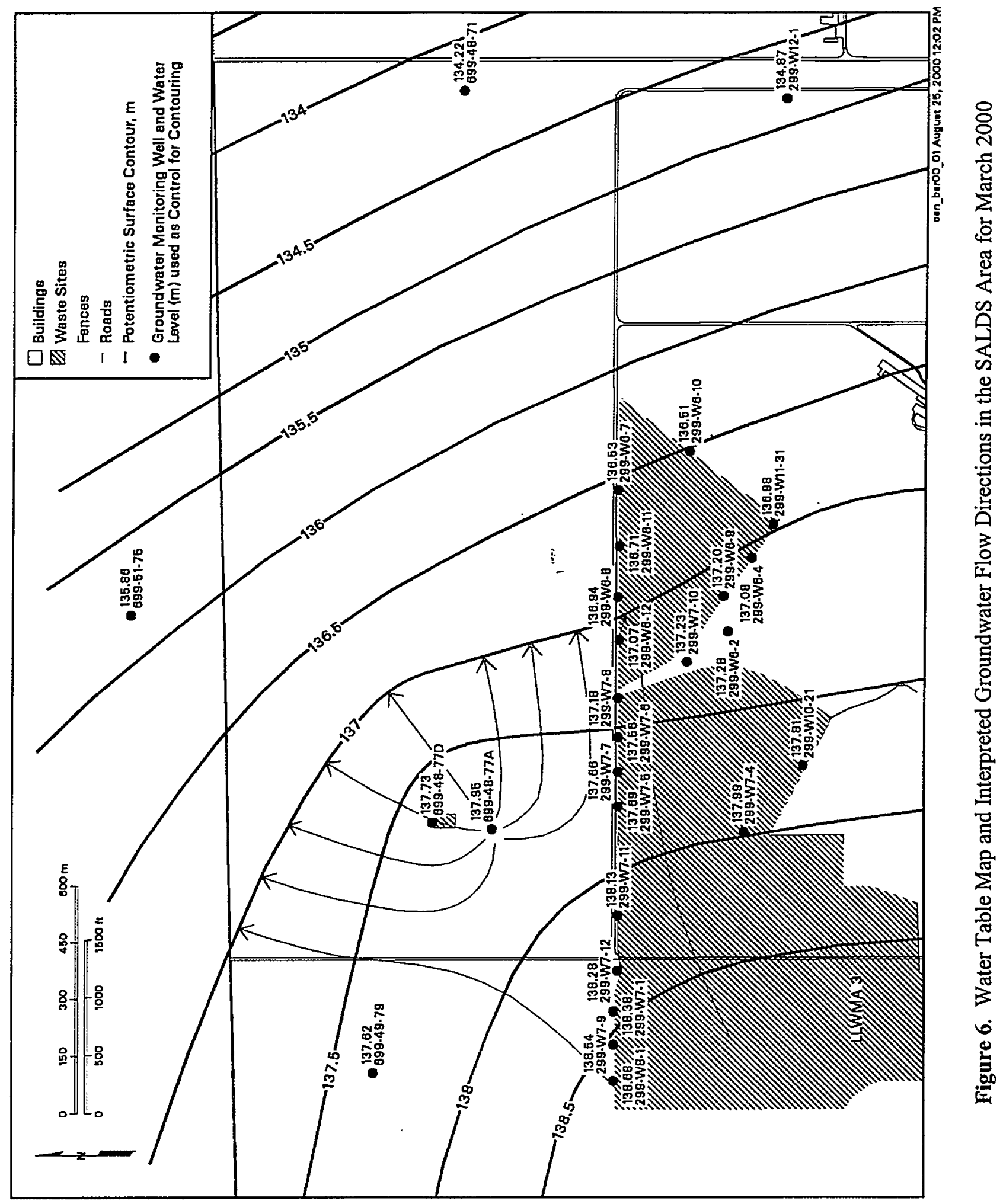




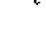




\subsection{Results of Groundwater Analyses for Tritium}

Results of tritium analyses in the SALDS tritium-tracking well network for FY 2000 are shown on Figure 7 and listed in Appendix A. Wells in the SALDS proximal network (699-48-77A, 699-48-77C, and 699-48-77D) have been affected by SALDS tritium discharges since 1996. Average tritium activities in well 699-48-77D in FY 2000 decreased from that of FY 1999 activities, whereas well 699-48-77A showed an intermittent increase. Only well $699-48-77 \mathrm{C}$, which is the deeper well in the proximal SALDS network, has showed a steady increase in tritium activities since 1998. Wells 299-W6-7, 299-W6-8, 299-W6-11, and 299-W6-12 continue to show the effects of the decaying tritium plume originating from the northeast portion of the 200 West Area.

Figure 8 illustrates the trends in tritium activities in the three SALDS proximal wells (see Figure 7 for location). Well 699-48-77A was first affected by discharges in August of 1996. Although this well is furthest away from the facility of the three "proximal" SALDS wells, subsurface geologic factors allowed the effluent to reach this well before any others (see Barnett et al. 1997). This well produced a maximum tritium activity during FY 2000 of $150,000 \mathrm{pCi} / \mathrm{L}$ (October 1999), which is $10,000 \mathrm{pCi} / \mathrm{L}$ higher than the FY 1999 maximum. Well 699-48-77D is nearest the SALDS, but showed tritium incursion only as recently as September 1997. The maximum tritium result for this well in FY 2000 was $420,000 \mathrm{pCi} / \mathrm{L}$ (October 1999), which is down from a maximum of $610,000 \mathrm{pCi} / \mathrm{L}$ in FY (July) 1999. Well 699-48-77C is screened $\sim 20 \mathrm{~m}$ deeper in the aquifer than $77 \mathrm{~A}$ and $77 \mathrm{D}$. Because of its deeper position, tritium incursions from SALDS operation have been historically lower in activity and intermittent in this well until recently. During times of high discharge the hydraulic head beneath the SALDS is increased and effluent is forced deeper into the aquifer. In July 2000 , a historically high tritium activity of $710,000 \mathrm{pCi} / \mathrm{L}$ was measure in well $699-48-77 \mathrm{C}$, indicating that the downward-moving SALDS effluent from earlier, tritium-rich discharges is now reaching this location in considerable strength.

Four of the wells along the border of the 200 West Area, generally southeast of the SALDS, have produced elevated values for tritium as a result of historical disposal practices in the 200 West Area. As shown in Figure 9, tritium activities in these wells have generally decreased or remained the same over the past several years. Recent changes in this trend are indicated in wells 299-W7-3 and 299-W7-7. Well 299-W7-3 produced the first detectable result $(1,400 \mathrm{pCi} / \mathrm{L})$ in the history of sampling in this well, suggesting that tritium from the SALDS or 200 West Area sources may have arrived at this location (see discussion in Section 5.0). The detections shown in Figure 9 for this well during 1991 and 1992 are probably nondetects in actuality, but appear as detections only because no " $u$ " (nondetect) qualifier accompanied the results in the database. Well 299-W7-7 has not produced a detectable result since early 1997 , but produced a result ( $300 \mathrm{pCi} / \mathrm{L})$ marginally above detection in August 2000 . Tritium in well 299-W6-11 was slightly higher in the FY 2000 sample $(6,000 \mathrm{pCi} / \mathrm{L})$ than in the FY 1999 sample $(5,700 \mathrm{pCi} / \mathrm{L})$, but the overall trend in this well remains downward.

Well 299-W8-1 is nearly $1 \mathrm{~km}$ away from the facility, and is thus far unaffected by discharges to the SALDS. This well produced one marginally-detectable tritium result of $220 \mathrm{pCi} / \mathrm{L}(\mathrm{MDA}=184 \mathrm{pCi} / \mathrm{L})$ in July 1999, and a result of $290 \mathrm{pCi} / \mathrm{L}$ in April of 2000 . However, both of these results were followed by results below detection. Also, this well has historically produced higher results prior to SALDS operation. 


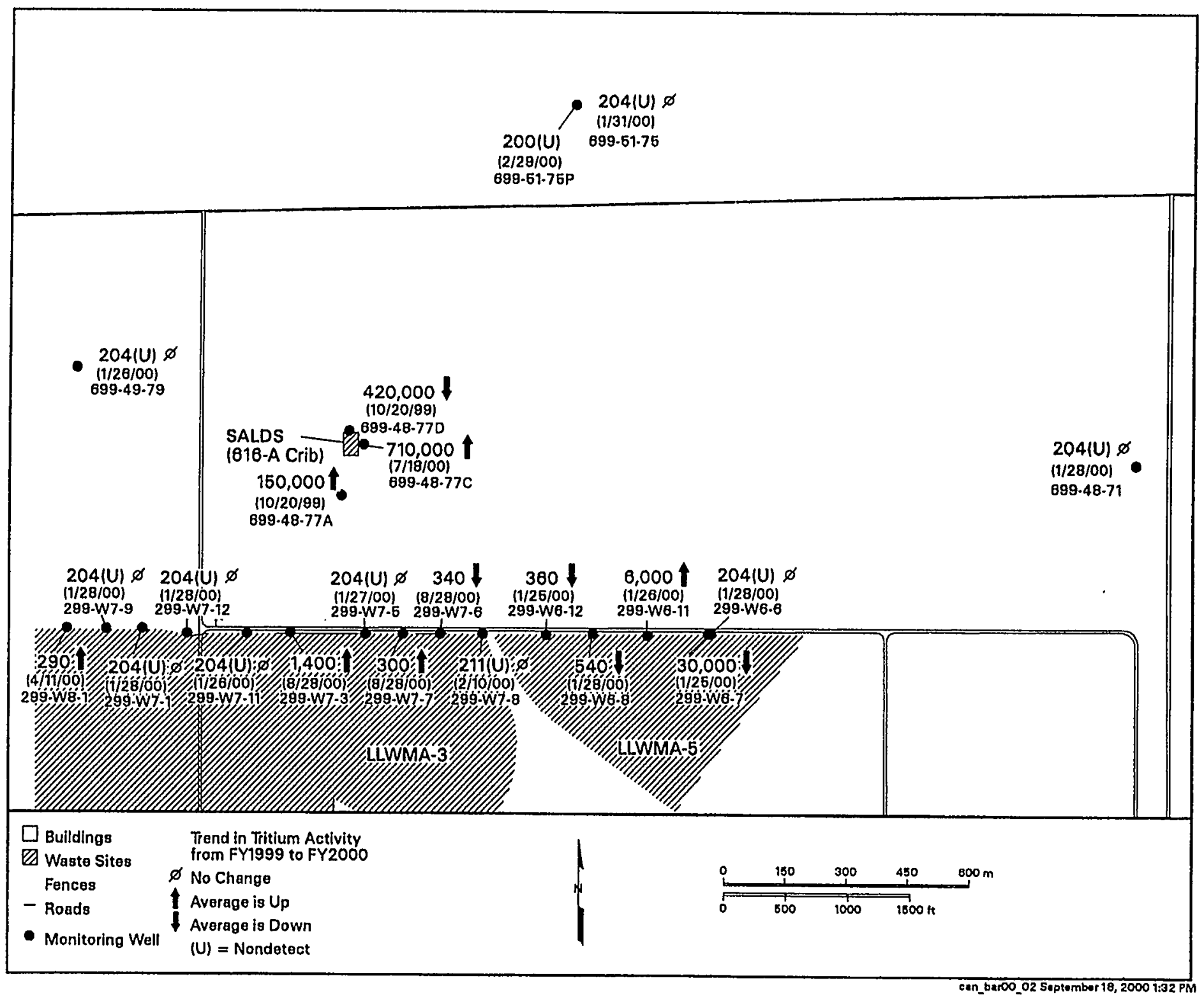

Figure 7. Maximum Tritium Activities in Groundwater for the SALDS Tritium-Tracking Network for FY 2000, Indicating (date of measurement) Change from FY 1999 


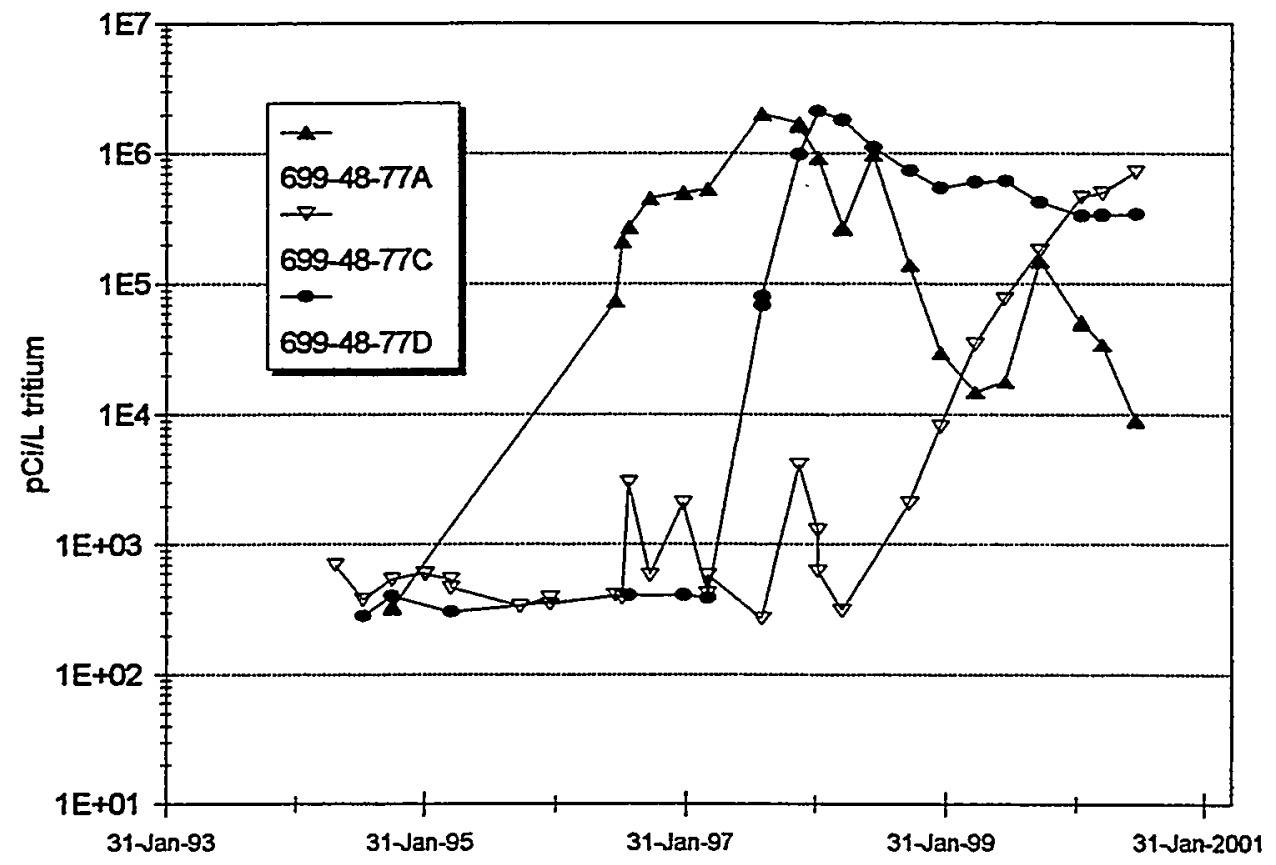

Figure 8. Tritium Activity Trends in SALDS Proximal Wells Through August 2000. Well $699-48-77 \mathrm{C}$ is completed $\sim 20 \mathrm{~m}$ deeper in the aquifer than wells 699-48-77A and 699-48-77D. 
Tritium

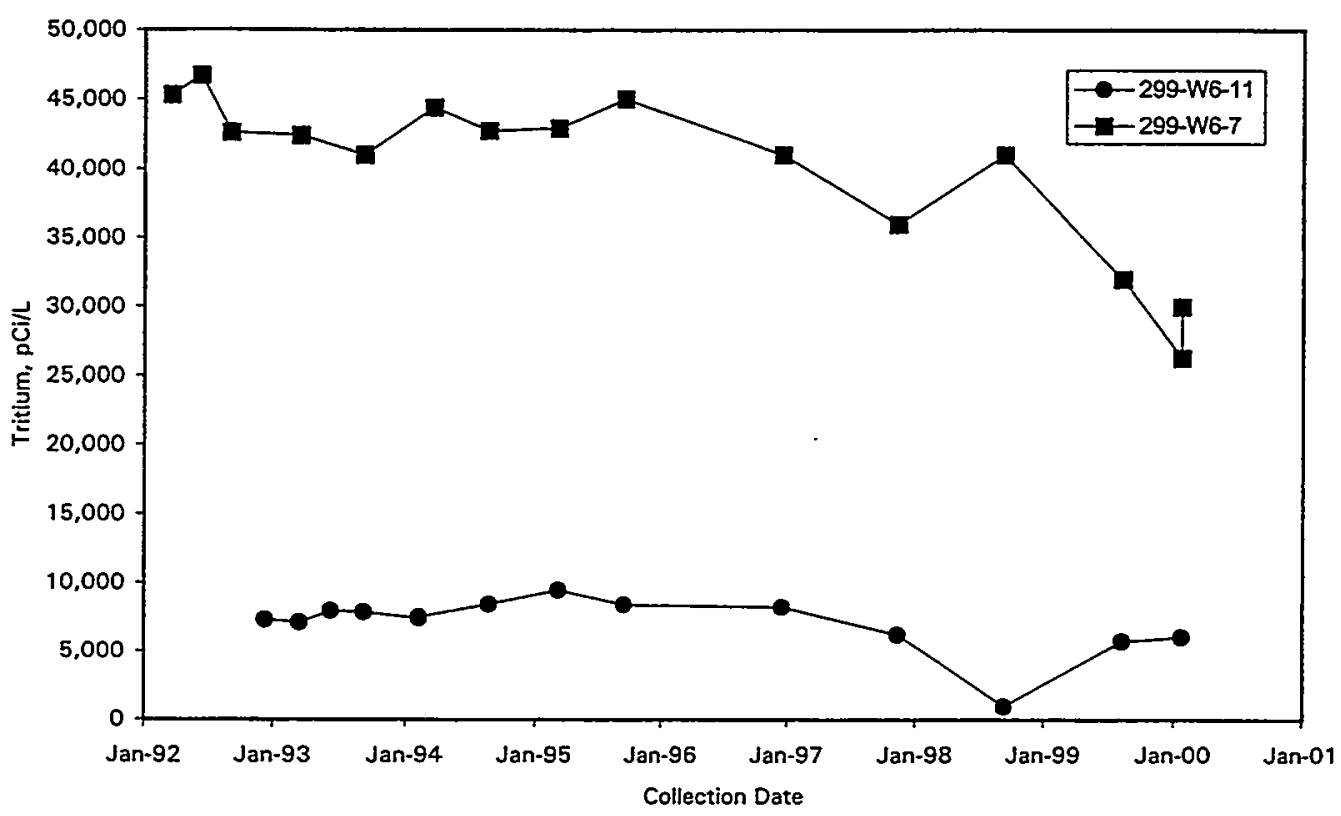

Open symbols used for non-detect values

JrRo0000

Tritium

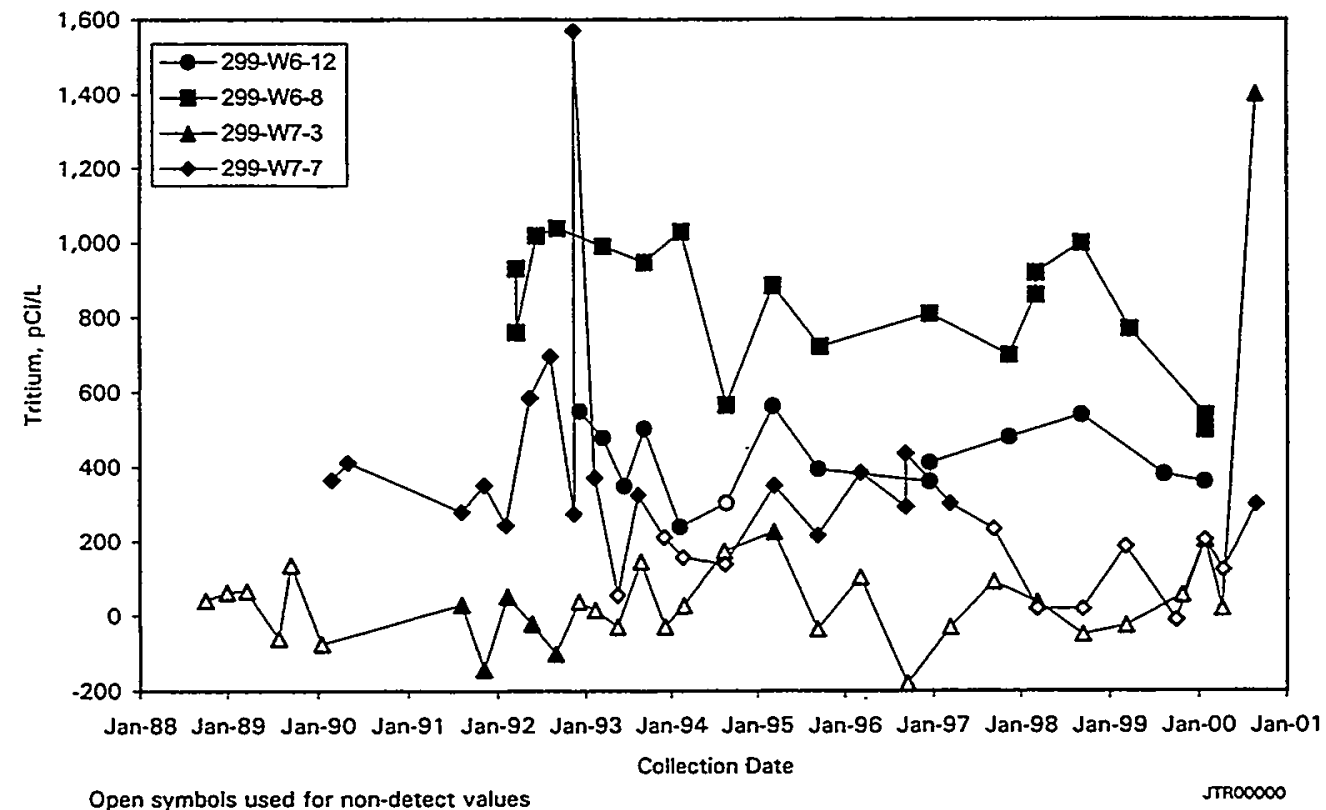

Figure 9. Tritium Activity Trends in Wells Southeast of the SALDS, Showing Remnant Effects of the Tritium Plume from the 200 West Area, and Recent Changes in Trends for Wells 299-W7-3 and 299-W7-7. The high value for well 299-W7-7 is suspected to be erroneous, with a duplicate on this date producing a result in line with the historic range. 


\subsection{Other Constituents in Groundwater}

In addition to tritium, groundwater from the SALDS proximal wells (699-48-77A, 699-48-77C, and 699-48-77D) and well 299-W8-1 were analyzed for a list of 16 constituents required by the State Waste Discharge Permit ST-4500 Special Condition S1 (A). Enforcement limits were set for most of these constituents [acetone, ammonia, benzene, cadmium (total), chloroform, copper (total), lead (total), mercury (total), $\mathrm{pH}$, sulfate, tetrahydrofuran, total dissolved solids (TDS)]. Gross alpha, gross beta, strontium-90, and tritium are not assigned enforcement limits, but are monitored and reported. Maximum concentrations for these constituents, and the corresponding sample months for FY 2000, are listed in Table 1.

Of the 12 constituents with permit limits, all were below the ST-4500 enforcement limits for groundwater during FY $2000^{\prime}$. Acetone, ammonia, benzene, tetrahydrofuran, and mercury results were all below detection limits in all four wells for all of FY 2000.

Chloroform was below detection in all wells except 299-W8-1, where it was below the assigned confidence level for quantitation, as determined by the laboratory (indicated as " $\mathrm{J"}$ " in Table 1). These results are a departure from FY 1999 when all but well $699-48-77 \mathrm{D}$ produced chloroform results above detection.

Total concentrations for the metals cadmium, copper, lead, and mercury were within groundwater permit limits for all results during FY 2000. Mercury was below detection in all wells during FY 2000, whereas during FY 1999, well 299-W8-1 produced one detectable result of this element. Cadmium was below detection in all results from wells 699-48-77C and 699-48-77D during FY 2000. In FY 1999, all wells produced at least one result of cadmium above detection. Well 699-48-77A produced anomalous results for copper and lead (still below enforcement levels) of 43.8 and $23.7 \mu \mathrm{g} / \mathrm{L}$, respectively. However, both of these results were accompanied by duplicate results within historically normal concentrations. The duplicate result for copper is $1.9 \mu \mathrm{g} / \mathrm{L}$, and three duplicates for lead were all below detection $(<1.5 \mu \mathrm{g} / \mathrm{L})$.

Well 699-48-77A produced an individual (not averaged quadruplicate measurements) laboratory result for $\mathrm{pH}$ that was anomalously low (6.99). However, corresponding averages of field $\mathrm{pH}$ results from the same sampling event were in line with a historic average of 8.08 , and indicate that the isolated laboratory result is not representative.

FY 2000 maxima for gross alpha and gross beta results were all within Hanford Site background (Johnson 1993; DOE/RI 1997) ranges for these two indicators, and generally lower than corresponding results from FY 1999. The highest gross alpha result for FY 2000 of $2.2 \mathrm{pCi} / \mathrm{L}$ was recorded for well 699-48-77C in February 2000. Gross beta was highest in well 299-W8-1, with a maximum result of $4.2 \mathrm{pCi} / \mathrm{L}$.

\footnotetext{
${ }^{1}$ Period reported is October 1, 1999 through August 31, 2000.
} 
Strontium-90 is the only radionuclide (other than tritium) that is specifically monitored at the SALDS, and was detected in all three proximal wells and well 299-W8-1 during FY 2000. This is a departure from FY 1999, when wells 299-W8-1 and 699-48-77A produced no detections of strontium-90. Nevertheless, activities of this radionuclide remain low, with the highest in FY 2000 measured in well 299-W8-1 at $5.4 \mathrm{pCi} / \mathrm{L}$.

Coincident with the first detection of elevated tritium in late 1996, concentrations of sulfate and a few other parameters were also found to have increased in groundwater from well 699-48-77A. These occurrences were interpreted to be a result of the dilute (clean water) effluent from SALDS dissolving soluble mineral species (mostly gypsum) in the vadose zone during infiltration (Thornton 1997, Barnett et al. 1997). Figures 10 through 12 show the trends for some of the parameters that best reflect this phenomenon; e.g., sulfate, conductivity, and TDS. Other species, such as calcium and sodium, show a more subdued response during the same time period. The trends are most pronounced in wells $699-48-77 \mathrm{~A}$ and 699-48-77D because these wells are screened at the water table. Since the period of late 1996 to late 1997, these parameters have trended downward, except for recent incursions in well 699-48-77C, which is screened $\sim 20 \mathrm{~m}$ below the water table. The effects of this event have only recently penetrated deeply enough into the aquifer to affect this well. Levels of some parameters, such as conductivity, may still be rising at this depth.

In wells 699-48-77A and 699-48-77C, all six parameters appear to have fallen below the initial background concentrations of these in groundwater. Concentrations that are more characteristic of the dilute effluent from the SALDS has replaced the natural levels to a minor degree.

Occasional "spikes" of these and related parameters may be expected to occur sporadically at any of the SALDS proximal wells, but at lower levels of concentration than in the original occurrences. Well 299-W8-1 thus far shows no evidence of SALDS effects. 
Table 1. Maximum Concentrations of Constituents with Permit Enforcement Limits in Groundwater and Corresponding Sample Month, SALDS, FY 2000

\begin{tabular}{|c|c|c|c|c|}
\hline Constituent (permit limit) & Well 299-W8-1 & Well 699-48-77A & Well $699-48-77 \mathrm{C}$ & Well 699-48-77D \\
\hline Acetone (160) & (u) & (u) & (u) & (u) \\
\hline Ammonia $(1,100)$ & (u) & (u) & (u) & (u) \\
\hline Benzene (5) & (u) & (u) & (u) & (u) \\
\hline Cadmium, total (10) & $0.53-$ Oct 99 & 0.83 -Oct 99 & (u) & (u) \\
\hline Chloroform (6.2) & $0.4(\mathrm{~J})-A p r 2000$ & (u) & (u) & (u) \\
\hline Copper, total (70) & 2.16 -Oct 99 & $43.8^{(\mathrm{a})}-\mathrm{Jul} 2000$ & 2.52-Jul 2000 & 2.82 - Oct 99 \\
\hline Lead, total $(50)$ & $6.95(J)-$ Oct 99 & $23.7^{(\mathrm{a})}-\mathrm{Jul} 2000$ & 2.57 -Oct 99 & $20.3^{(2)}-$ Oct 99 \\
\hline Mercury, total (2) & (u) & (u) & (u) & (u) \\
\hline $\begin{array}{l}\text { Laboratory } \mathrm{pH}, \mathrm{pH} \text { units } \\
(6.5-8.5)\end{array}$ & $7.99-8.11$ & $6.99^{(\mathrm{a})}-8.19$ & $7.6-7.95$ & $7.94-8.11$ \\
\hline $\begin{array}{l}\text { Field pH, pH units } \\
(6.5-8.5) \\
\end{array}$ & $8.13-8.24$ & $8.08-8.19$ & $7.62-7.97$ & $7.89-8.20$ \\
\hline Sulfate $(250,000)$ & 46,990 - Jul 2000 & 3,873 -Oct 99 & 50,080 -Oct 99 & 11,320 -Apr 2000 \\
\hline Tetrahydrofuran (100) & (u) & (u) & (u) & (u) \\
\hline $\begin{array}{l}\text { Total Dissolved Solids } \\
(500,000)\end{array}$ & $265,000-F e b 2000$ & 144,000 —Jul 2000 & $249,000-A p r 2000$ & 175,000 -Jul 2000 \\
\hline Gross Alpha $(\mathrm{pCi} / \mathrm{L})^{(\mathrm{b})}$ & $2.2-$ Oct 99 & $1.57-\mathrm{Jul} 2000$ & 2.2-Feb 2000 & $\begin{array}{c}1.2-\text { Oct } 99 / \\
\text { Apr } 2000\end{array}$ \\
\hline Gross Beta (pCi/L) & 4.2 -Oct 99 & $2.4-\mathrm{Apr} 2000$ & 2.8-Apr 2000 & $2.1-F e b 2000$ \\
\hline Strontium-90 (pCi/L) ${ }^{(b)}$ & $5.4-$ Oct 99 & 3.6 - Jul 2000 & 4.9-Jul 2000 & 2.9-Jul 2000 \\
\hline Tritium $(\mathrm{pCi} / \mathrm{L})^{(\mathrm{b})}$ & $290-\operatorname{Apr} 2000$ & $150,000-$ Oct 99 & $710,000-J u l 2000$ & 420,000 - Oct 99 \\
\hline \multicolumn{5}{|c|}{$\begin{array}{l}\text { 1. All concentrations in } \mu \mathrm{g} / \mathrm{L} \text { unless noted. } \\
\text { 2. "(u)" = not detected } \\
\text { 3. "(J)" = estimated quantity (concentration is below laboratory internal standards for accurate quantitation). }\end{array}$} \\
\hline $\begin{array}{l}\text { (a) Anomalous reading-st } \\
\text { (b) Constituent is not assi } \\
\text { (c) Entire range of readin }\end{array}$ & $\begin{array}{l}\text { text for discussion. } \\
\text { ed an enforcement lim } \\
\text { for FY } 2000 \text { (October }\end{array}$ & \multicolumn{2}{|c|}{$\begin{array}{l}\text { (b) Constituent is not assigned an enforcement limit, but is subject to routine monitoring and reporting. } \\
\text { (c) Entire range of readings for FY } 2000 \text { (October 1, } 1999 \text { through August } 31,2000 \text { ). }\end{array}$} & \\
\hline
\end{tabular}



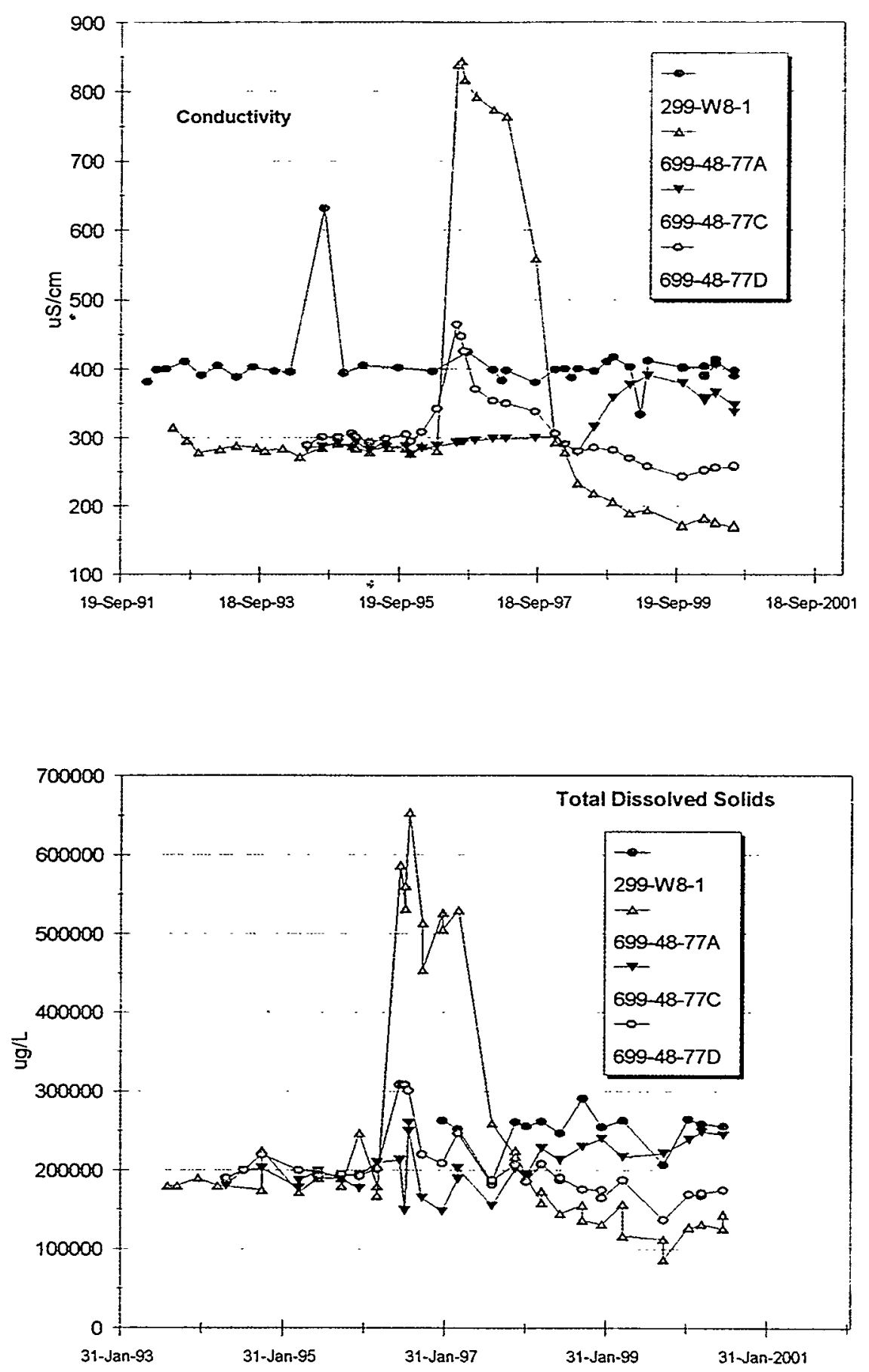

Figure 10. Trend Plots for Conductivity and Total Dissolved Solids in SALDS Proximal Wells and Well 299-W8-1 

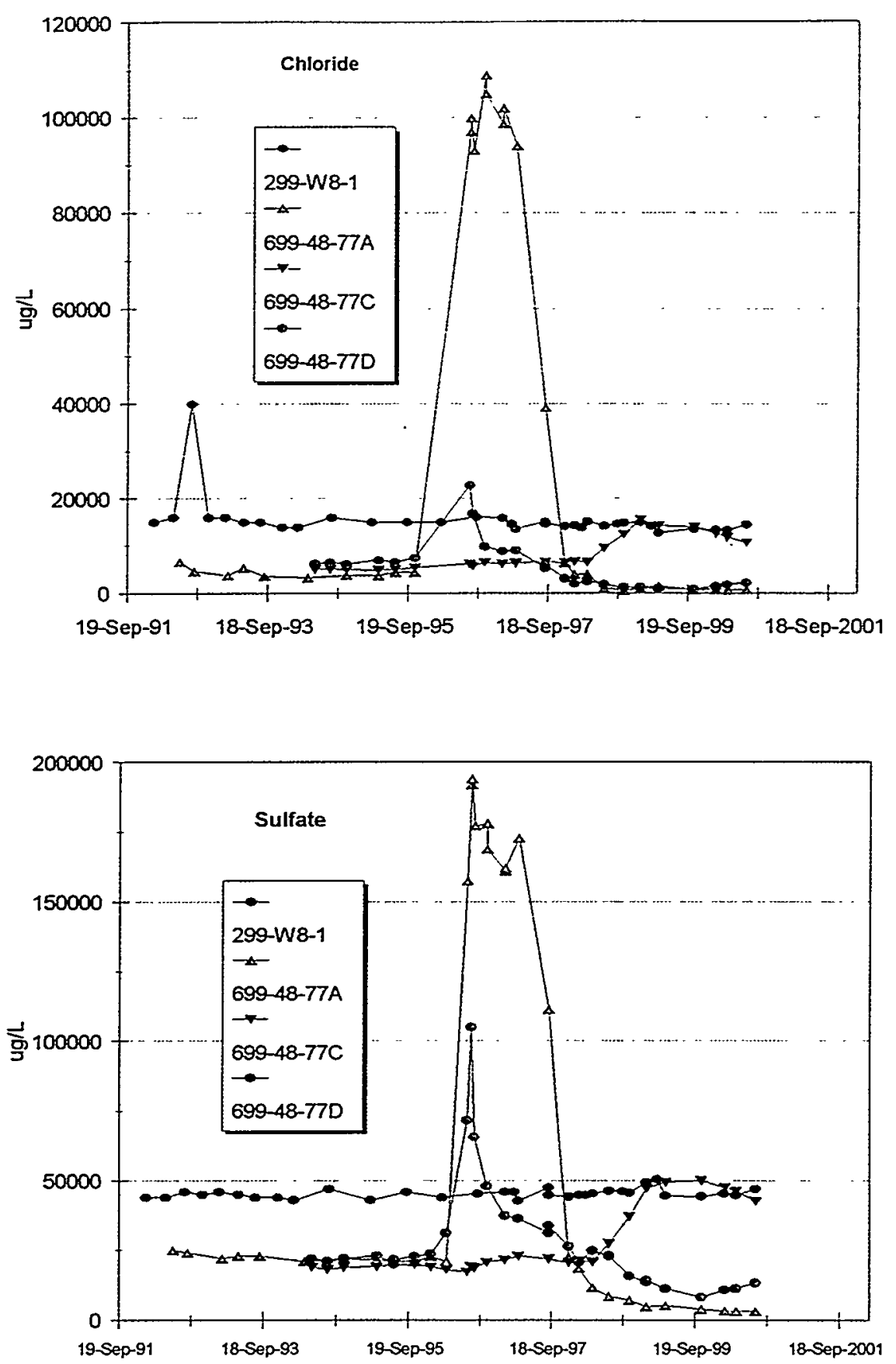

Figure 11. Trend Plots for Chloride and Sulfate in SALDS Proximal Wells and Well 299-W8-1 

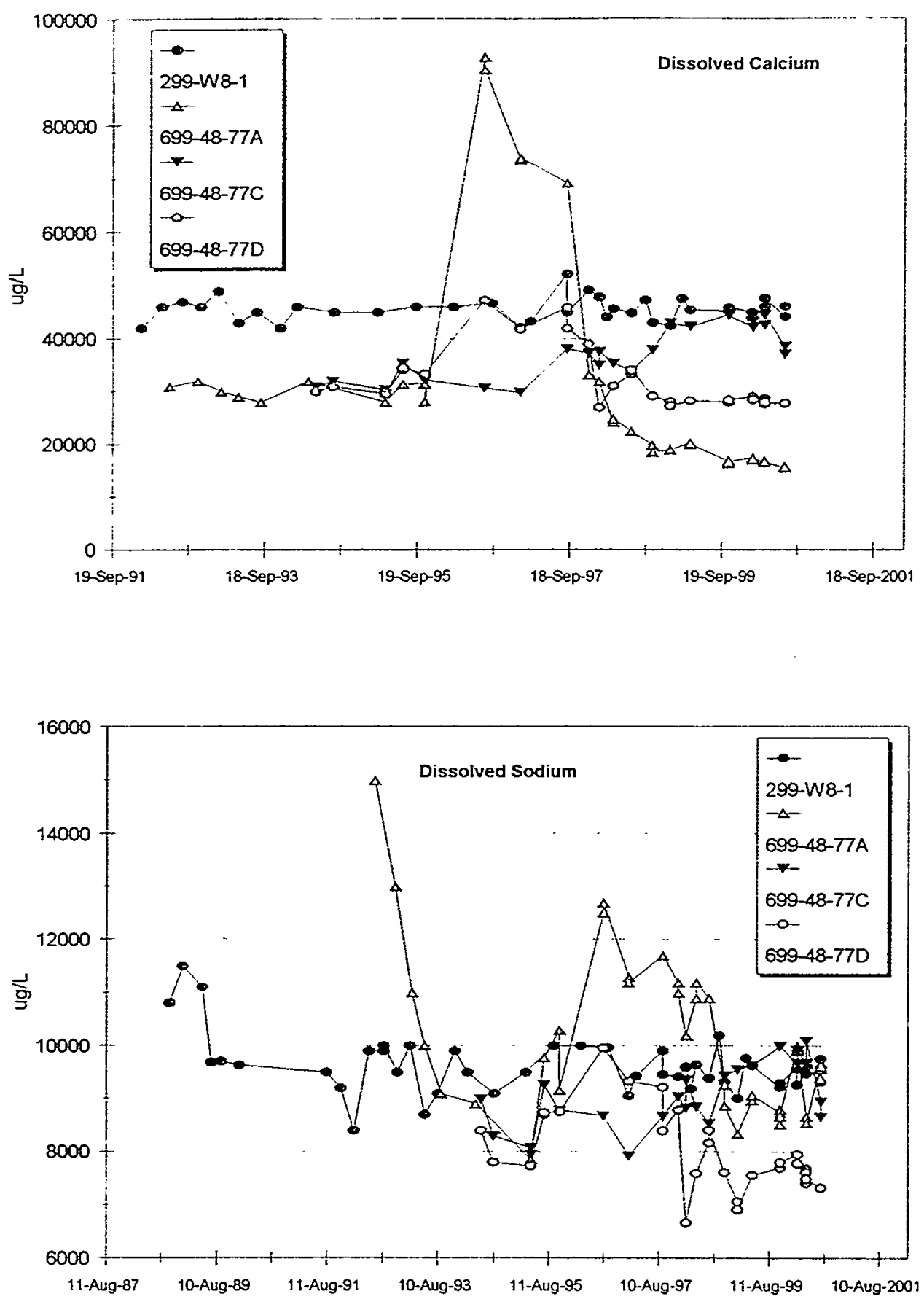

Figure 12. Trend Plots for Dissolved Calcium and Dissolved Sodium for SALDS Proximal Wells and Well 299-W8-1 


\subsection{Discussion and Recommendations}

Water levels in SALDS wells continue to reflect the influence of two opposing trends; the general decline of head in the uppermost aquifer because of cessation of 200 West Area activities, and mounding in the immediate vicinity of SALDS from continued effluent disposal at the facility. Based on the probable occurrence of SALDS-derived tritium in well 299-W7-3 (see below), it appears that groundwater flow induced by the SALDS mound may extend slightly further to the south than is depicted by the flow-potential lines in Figure 6. Given the configuration of the water table in this region, it is unlikely that the occurrence of tritium in this well is the result of migration of the historical plume originating from the 200 West Area.

Wells immediately south to southeast of the SALDS along the 200 West Area northern boundary may be on the southern edge of the SALDS tritium plume, as suggested by the recent results in well 299-W7-3. This well is completed at the bottom of the aquifer $\sim 70 \mathrm{~m}$ below the water table. However, tritium was first detected at the water table in well 699-48-77A, having moved southward from the SALDS to reach this well. It is possible that the detection of tritium in well 299-W7-3 represents the arrival of the lower edge of the SALDS tritium plume at this location, and does not suggest that tritium is moving exclusively along the bottom portion of the aquifer, but that the tritiated water disposed at SALDS is being pushed lower in the aquifer by the disposal of non-tritiated water.

The current numerical groundwater/tritium model (Cole and Wurstner in Barnett et al. 1997) indicated that tritium would first arrive at the 200 West Area northern boundary in 2000 , and would then be detectable in as many as three wells along this boundary. In this model, well 299-W7-3 is less than 100 m outside the area of the predicted plume, with wells 299-W7-5, 299-W7-6, and 299-W7-7 lying inside the $500 \mathrm{pCi} / \mathrm{L}$ portion (lowest practically detectable) portion of the plume. The occurrence of tritium in well 299-W7-3 constitutes virtual agreement with the model. The fact that tritium arrived as predicted in year 2000 very near the predicted locations, and within a factor of 2 of predicted concentrations, represents an exemplary performance by the model, and suggests that the effects of tritium disposal to groundwater are being accurately anticipated. Thus, is it recommended that reapplication of the groundwater model be reserved for an occurrence that represents a recognizable departure from model prediction. As an interim measure, it is recommended that the frequency of tritium sampling at wells 299-W7-3, 299-W7-5, 299-W7-6, and 299-W7-7 be temporarily increased to quarterly. Wells 299-W7-5, and 299-W7-6 have not produced detectable tritium results to date, and the result in well 299-W7-7 is problematic as to source, but all are in advantageous locations to reveal expansion of the SALDS tritium plume. This measure will assist in a more accurate determination of the southern bounds of the SALDSgenerated tritium plume, provide estimates of travel time for model comparisons, and help preserve the distinction between this plume and the older 200 West tritium plume further east. Because well 299-W7-3 is completed at a deep level in the aquifer ( $140 \mathrm{~m}$ below land surface) it could indicate that tritium forced deeper into the aquifer in the vicinity of the SALDS is migrating southward. This circumstance would have important implications for accurate, future modeling. Further observation on a quarterly basis will be necessary to help resolve these questions. 
Trends in concentrations of anions, certain metals, and indicators (see Section 4.0) in groundwater beneath the SALDS indicate an initial leaching of natural soil salts, followed by a recent dilutive event resulting in depression of concentrations below background. This sequence is illustrated in wells 699-48-77A and 699-48-77D, especially for conductivity, chloride, and sulfate. Well $699-48-77 \mathrm{C}$ is still reflecting the early part of this sequence-several of these parameters are at or near all time high concentrations in this well. Because of its position deeper in the aquifer, the effects of these dissolved components are more subdued than the wells completed at the water table. In the future, fluctuations in concentrations of these constituents may occur as volumes and/or duration of discharge events to the SALDS vary. The strength of the response (i.e., concentrations) observed in groundwater will depend on how long the effluent has to equilibrate with aquifer solids, but it is unlikely that concentrations as high as those observed in the first incursion of these constituents will recur. 


\subsection{References}

Barnett, D. B. 2000. Groundwater Monitoring and Tritium-Tracking Plan for the 200 Area StateApproved Land Disposal Site. PNNL-13121, Pacific Northwest National Laboratory, Richland, Washington.

Barnett, D. B., M. P. Bergeron, C. R. Cole, M. D. Freshley, and S. K. Wurstner. 1997. Tritium Monitoring in Groundwater and Evaluation of Model Predictions for the Hanford Site 200 Area Effluent Treatment Facility. PNNL-11665, Pacific Northwest National Laboratory, Richland, Washington.

DOE-RL. 1997. Hanford Site Background: Part 3, Groundwater Background. DOE/RL-96-61. U.S. Department of Energy, Richland Operations Office, Richland, Washington.

Johnson, V. G. 1993. Westinghouse Hanford Company Operational Groundwater Status Report, 19901992. WHC-EP-0595, Westinghouse Hanford Company, Richland, Washington.

Thornton, E. C. 1997. Origin of Increased Sulfate in Groundwater at the ETF Disposal Site. PNNL11633, Pacific Northwest National Laboratory, Richland, Washington. 


\section{Appendix A}

SALDS Tritium Results in Groundwater for FY 2000 
Table A.1. SALDS Tritium Results During FY 2000 (through August 2000)

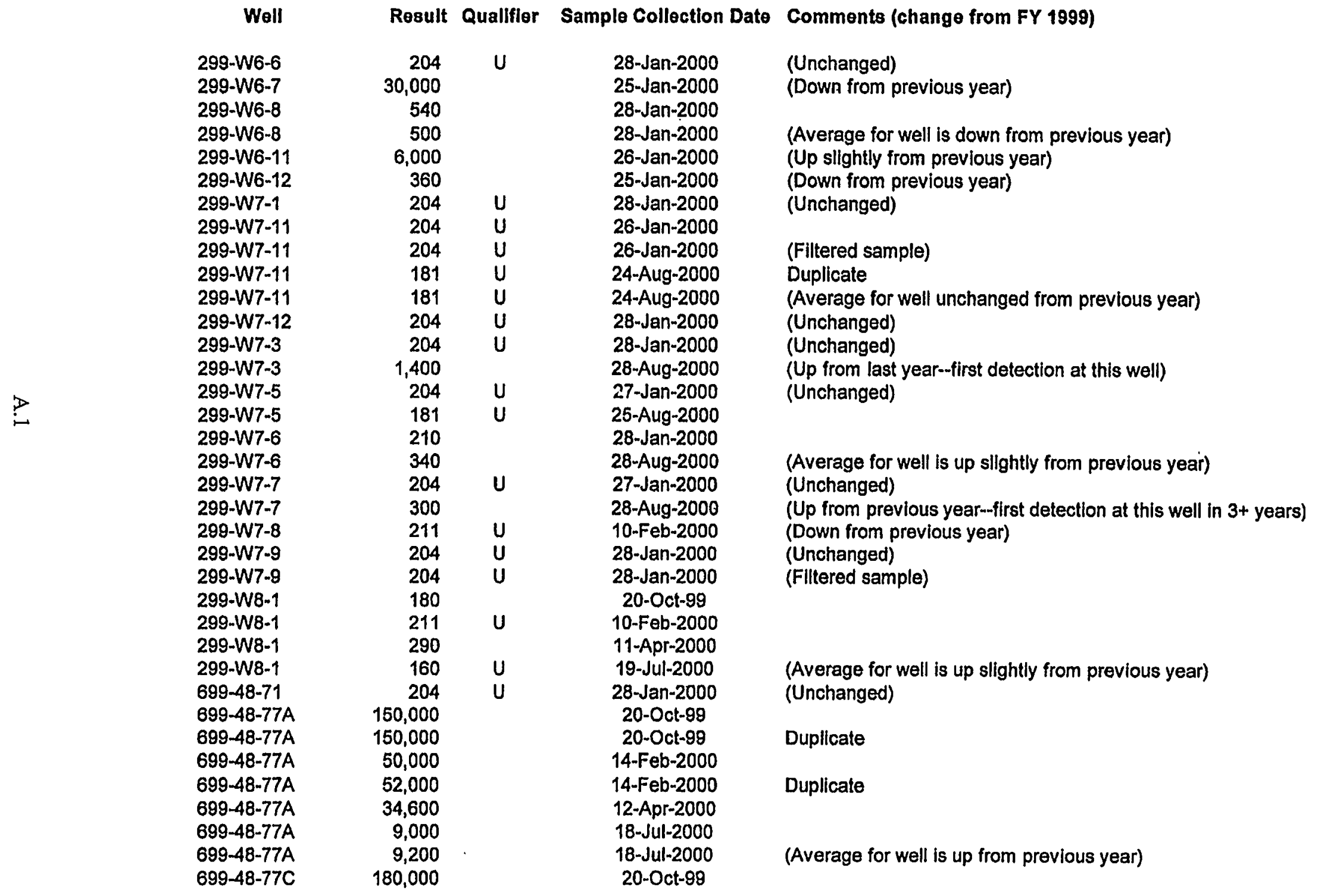


Table A.1. (contd)

Well Result Quallfier Sample Collection Date Comments (change from FY 1999)

$699-48-77 C$
$699-48-77 C$
$699-48-77 C$
$699-48-77 C$
$699-48-77 D$
$699-48-77 D$
$699-48-77 D$
$699-48-77 D$
$699-48-77 D$
N $\quad 699-49-79$
$699-49-79$
$699-51-75$
$699-51-75$
$699-51-75 P$

699-51-75P

460,000
490,000
710,000
77,000
420,000
330,000
336,000
330,000
340,000
204
204
204
181
200

14-Feb-2000

11-Apr-2000

18-Jul-2000

13-Jul-99

20-Oct-99

14-Feb-2000

11-Apr-2000

11-Apr-2000

18-Jul-2000

28-Jan-2000

28-Jan-2000

31-Jan-2000

24-Aug-2000

29-Feb-2000
(Average for well is up significantly --deep well)

\author{
Duplicate \\ (Average is down from previous year) \\ (Unchanged) \\ Duplicate \\ Duplicate \\ (First sampling event in this well for SALDS monitoring)
}

All results in $\mathrm{PC} / \mathrm{L}$

Qualifiers: $U=$ nondetect 


\section{Distribution}

No. of

Copies

ONSITE

5 DOE Richland Operations Office
M. J. Furman
R. D. Hildebrand
G. Richardson
G. L. Sinton
K. M. Thompson

14 Fluor Hanford, Inc.

D. L. Flyckt

K. J. Lueck
No. of

Copies

P. M. Olson (10)

S6-72

D. K. Smith

S6-71

R. W. Szelmeczka

S6-72

A5-13

A5-13

$\mathrm{H} 0-12$

H0-12

A5-13

Barnett (10)

K6-81

M. P. Bergeron

K9-36

M. J. Hartman

K6-96

S. P. Luttrell

K6-96

W. J. Martin

K6-81

Information Release Office (7) 